\title{
Neonatal Hyperglycaemia: Case Report with Plasma Insulin Studies
}

\author{
ISABELLA C. FERGUSON \\ From the Department of Child Health, University of Glasgow
}

It is now established that the dysmature infant, of low birthweight for the period of gestation, may develop a diabetic state in the neonatal period (Arey, 1953; Engleson and Zetterqvist, 1957; Hutchison, Keay, and Kerr, 1962). This condition, which is temporary and has a good prognosis, has to be distinguished from other causes of hyperglycaemia. Permanent diabetes mellitus occurs rarely in the neonatal period (Guest, 1949; Gans, 1953; HofmanBang, 1954). Ketosis and acetonuria occur in these cases whereas this is not a feature in the temporary type. Infection and cerebral damage may also cause hyperglycaemia and in some of the reported cases of neonatal diabetes this may have been a factor (Strandqvist, 1932; Lewis and Eisenberg, 1935; Limper and Miller, 1935; Devine, 1938).

Hyperglycaemia associated with dysmaturity is uncommon, though probably not so rare as reported cases would suggest. More commonly, hypoglycaemia may develop during the first few days after birth (Neligan, Robson, and Watson, 1963; Neligan, 1965; Shelley and Neligan, 1966; Campbell, Ferguson, Hutchison, and Kerr, 1967), and Chance and Bower (1966) reported a case of symptomatic hypoglycaemia where temporary hyperglycaemia developed later. The nature of the abnormality in these conditions is uncertain and insulin studies have been limited. A case is described here in which insulin studies were made on the first day of life because of dysmaturity, when blood glucose was low (22 mg./100 ml.), and on the 6th day of life, when hyperglycaemia developed.

\section{Case Report}

The patient, a male infant, was born on February 11, 1966, one week after the expected date of delivery. He weighed $2510 \mathrm{~g}$., length was $49.5 \mathrm{~cm}$. His mother, an unmarried primigravida, had been well throughout pregnancy until the last two weeks when she had developed slight oedema, but no other signs of toxaemia.

Received December 6, 1966.
The placenta was unhealthy, showing areas of infarction and calcification, and weighed $450 \mathrm{~g}$. At birth he was limp and cyanosed, Apgar score at 2 minutes being 3, and he was resuscitated in hyperbaric oxygen. He showed signs of severe dysmaturity, having a pale dry wrinkled skin, and a marked absence of subcutaneous fat (Fig. 1).

$\mathrm{He}$ fed poorly from birth and vomited occasionally. In the first week of life he lost $0.35 \mathrm{~kg}$. Blood glucose before his first feed was $22 \mathrm{mg}$. $/ 100 \mathrm{ml}$. (glucose oxidase method, Marks, 1959). Thereafter, blood glucose was estimated frequently before feeds using the 'Dextrostix' enzyme strip test, and urine was tested daily for glycosuria. Until the fifth day blood glucose measured 40-65 $\mathrm{mg} . / 100 \mathrm{ml}$. and urine was sugar free. On the fifth day, urine contained $1 \%$ reducing substance, and this was shown by chromatography to comprise both glucose and

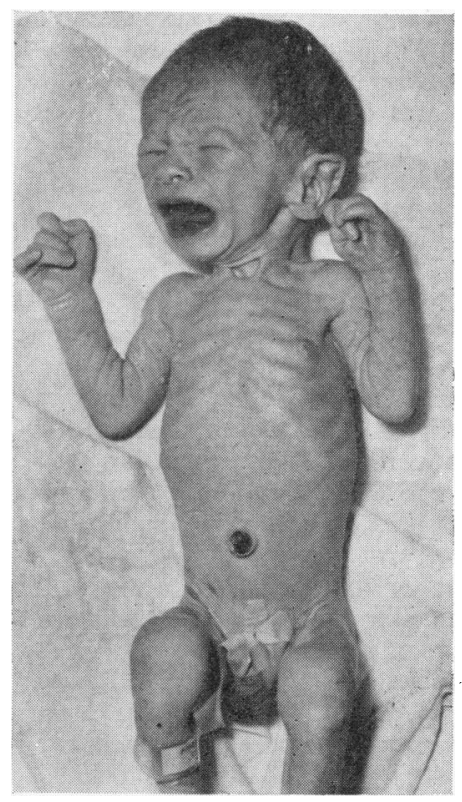

FIG. 1.-Patient at the age of 6 days showing dysmature appearance. 
normal traces of lactose. Fasting blood glucose was $65 \mathrm{mg} . / 100 \mathrm{ml}$. Glycosuria continued, and the following day blood glucose 3 hours after a feed was $236 \mathrm{mg}$./ $100 \mathrm{ml}$. An oral glucose tolerance test was performed after a 6-hour fasting period and gave the following result (Table 1 ).

\section{TABLE I}

Glucose Tolerance Test at Onset of Hyperglycaemia (age 6 days)

\begin{tabular}{|c|c|c|c|c|c|c|}
\hline \multicolumn{6}{|c|}{ Time After $5 \mathrm{~g}$. Glucose } & \multirow{2}{*}{$\begin{array}{c}\begin{array}{c}\text { Blood Glucose } \\
\text { (mg./100 ml.) }\end{array} \\
43 \\
278 \\
236 \\
286 \\
291 \\
327\end{array}$} \\
\hline $\begin{array}{l}\text { Fasting b } \\
\frac{1}{1} \text { hour } \\
1 \text { hour } \\
1 \frac{1}{2} \text { hours } \\
2 \text { hours } \\
3 \text { hours }\end{array}$ & $\begin{array}{l}\text { gluc } \\
\ldots \\
\ldots \\
\ldots \\
\ldots \\
\ldots\end{array}$ & $\begin{array}{l}\ldots \\
\cdots \\
\cdots \\
\cdots\end{array}$ & $\begin{array}{l}\cdots \\
\cdots \\
\cdots \\
\cdots\end{array}$ & $\begin{array}{l}\cdots \\
\cdots \\
\cdots \\
\cdots \\
\cdots\end{array}$ & $\begin{array}{l}\ldots \\
\ldots \\
\ldots \\
\ldots\end{array}$ & \\
\hline
\end{tabular}

As the fasting glucose was normal, insulin was withheld but glycosuria $0 \cdot 5-1 \%$ persisted, and blood glucose measured before 3-hourly feeds ranged between 200-250 $\mathrm{mg} . / 100 \mathrm{ml}$. There was a trace of proteinuria but no ketonuria. Blood urea was $117 \mathrm{mg} . / 100 \mathrm{ml}$. Serum electrolytes were normal. He continued to lose weight and developed slight dehydration. In view of these findings soluble insulin, 1 unit three times daily, was given when he was aged 10 days. The dose was increased gradually to 2 units eight times daily after 1 week, and he began to gain weight rapidly (Fig. 2). Blood glucose before feeds was around $50 \mathrm{mg} .100 \mathrm{ml}$. and glycosuria diminished to $0-0 \cdot 25 \%$. After 11 days of treatment insulin was reduced gradually and he was stabilized with insulin zinc suspension, 4 units daily. $\mathrm{He}$ remained well and continued to gain weight. Urine contained $0-0.5 \%$ glucose. He was never hypoglycaemic while having insulin, and psychomotor development at 9 weeks was considered normal. He then weighed $4 \cdot 14 \mathrm{~kg}$. and looked well (Fig. 3).

At the age of 10 weeks he developed pyrexia $\left(39^{\circ} \mathrm{C}\right.$.) without any apparent source of infection. Urine contained $2 \%$ protein, but there was no pyuria and culture was sterile. Fever continued intermittently and a few days later it was noted for the first time that the left kidney was palpably enlarged. Intravenous pyelogram showed poor renal function, an enlarged left kidney being outlined faintly after 45 minutes. The right kidney could not be seen. Cystogram was normal. Serum electrolytes: sodium 164 , chloride 127 , potassium $6 \cdot 9$, calcium $3 \cdot 25$, and standard bicarbonate $16 \mathrm{mEq} / \mathrm{l}$. Phosphorus $18 \cdot 5$, urea 440 , and cholesterol $409 \mathrm{mg} . / 100$ $\mathrm{ml}$. Serum was hyperlipaemic. Urine culture was sterile on three occasions, but in view of severe renal failure, ampicillin was given as a prophylactic measure.

At the age of 11 weeks, there had been no glycosuria for several days and insulin was withdrawn. Thereafter urine contained $0-0 \cdot 25 \%$ sugar, and 'Dextrostix' blood glucose readings, measured three times daily before feeds, ranged between $65-130 \mathrm{mg} . / 100 \mathrm{ml}$. Renal failure was progressive and he developed terminal uraemic twitching and convulsions. $\mathrm{He}$ died at the age $3 \frac{1}{2}$ months.

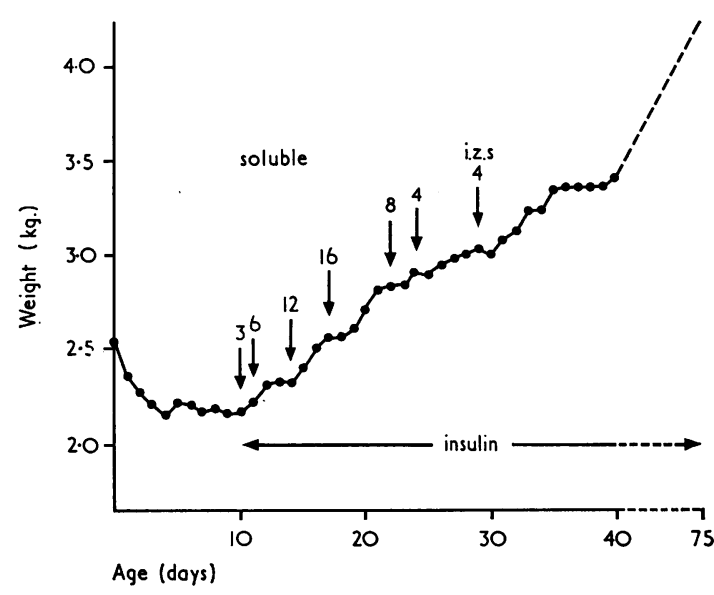

FIG. 2.-Chart showing weight gain during treatment with insulin.

Necropsy (Dr. C. H. W. Horne). The relevant findings were as follows.

Pancreas ( $1.8 \mathrm{~g}$.). A small circular organ $1 \mathrm{~cm}$. in diameter. Histological examination showed areas where there was an increase in the size and number of the ducts but the islets of Langerhans appeared normal.

Genito-urinary system. Bladder appeared normal. The left ureter was dilated and the right was small and atrophic. There was virtually no right kidney, all that

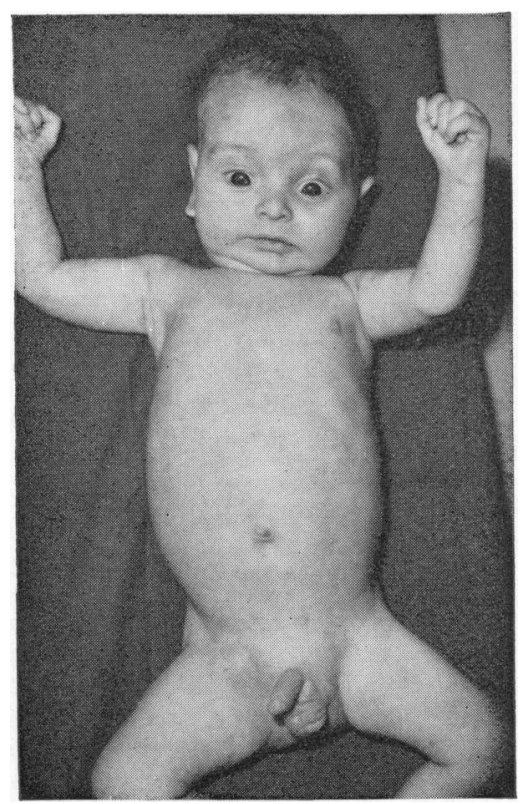

Fig. 3.-Patient at the age of 9 weeks showing satisfactory nutritional state. 
was present of this organ were a few small cysts embedded in what appeared to be fatty tissue. Left kidney (35 g.) was of normal size and its surface was studded with small cysts. On histological examination the left kidney showed polycystic disease. There were a few foci of chronic inflammatory cells. In the right kidney there were only a few aberrant glomeruli and dilated tubules, the remaining tissue being fibrous with small islands of cartilage.

Lungs. Basal congestion and early bronchopneumonia. On histological examination there was congestion and patchy alveolar collapse. Beneath the pleura, cysts lined by cuboidal epithelium were present.

Liver (220 g.). Mildly congested, a small angiomatous malformation was present.

\section{Insulin Studies}

Plasma insulin was measured by the immunoassay technique of Hales and Randle (1963). A fasting blood sample was taken after birth, just before the first feed, and the response to oral glucose, given by intragastric tube, was measured 30 minutes later.

Fasting plasma insulin $10 \mu \mathrm{U} / \mathrm{ml}$, , blood glucose 22 mg. $/ 100 \mathrm{ml}$; half an hour after $5 \mathrm{~g}$. glucose, plasma insulin $23 \mu \mathrm{U} / \mathrm{ml}$., blood glucose $78 \mathrm{mg} . / 100 \mathrm{ml}$.

When a glucose tolerance test was performed on the sixth day, plasma insulin was measured on each sample of blood with the following results (Table II). The insulin response to glucose is slightly greater than after birth.

TABLE II

Plasma Insulin Levels at Onset of Hyperglycaemia (age 6 days)

\begin{tabular}{|c|c|c|c|c|c|c|}
\hline \multicolumn{6}{|c|}{ Time (min.) After 5 g. Glucose } & Plasma Insulin $(\mu \mathrm{U} / \mathrm{ml})$. \\
\hline $\begin{array}{l}\text { Fasting } \\
30 \quad \ldots \\
60 \quad \ldots \\
90 \\
120 \ldots\end{array}$ & $\begin{array}{l}\ddot{ } \\
\ddot{*} \\
\ddot{*}\end{array}$ & $\begin{array}{l}\cdots \\
\cdots \\
\cdots \\
\cdots\end{array}$ & $\begin{array}{l}\cdots \\
\cdots \\
\cdots \\
\cdots\end{array}$ & $\begin{array}{l}\cdots \\
\cdots \\
\cdots \\
\cdots\end{array}$ & . & $\begin{array}{l}12 \\
36 \\
20 \\
18 \\
20\end{array}$ \\
\hline
\end{tabular}

Three days after the onset of glycosuria an intravenous tolbutamide tolerance test was performed after a 6-hour fasting period, with the following results (Table III). The fall in blood glucose at 20 minutes and increase in plasma insulin level are normal, suggesting that the pancreas secreted insulin normally in response to tolbutamide.

TABLE III

Intravenous Tolbutamide Tolerance Test (age 8 days)

\begin{tabular}{c|c|c}
\hline $\begin{array}{c}\text { Time (min.) After } \\
50 \text { mg. Tolbutamide }\end{array}$ & $\begin{array}{c}\text { Plasma Insulin } \\
(\mu \mathrm{U} / \mathrm{ml} .)\end{array}$ & $\begin{array}{c}\text { Blood Glucose } \\
\text { (mg./100 ml.) }\end{array}$ \\
\hline Fasting & 12 & 72 \\
20 & 23 & 55 \\
30 & 20 & 51 \\
60 & 15 & 65 \\
90 & 16 & 65 \\
120 & 14 & 58 \\
\hline
\end{tabular}

Finally, insulin studies were repeated on the third day of insulin treatment when he was having 2 units soluble insulin six times daily. Fasting plasma insulin was then $33 \mu \mathrm{U} / \mathrm{ml}$.; blood glucose $50 \mathrm{mg}$./100 ml. Half-an-hour after $5 \mathrm{~g}$. glucose +2 units of soluble insulin the plasma insulin was $133 \mu \mathrm{U} / \mathrm{ml}$; blood glucose $135 \mathrm{mg} . / 100 \mathrm{ml}$.

\section{Discussion}

Nineteen cases of temporary neonatal hyperglycaemia have been reported, and in all but four, the infant was dysmature. It is likely, however, that routine testing for glycosuria and frequent blood glucose estimations in such babies would yield a greater incidence, and in the present case an early diagnosis was made by such routine testing. An oral glucose test was performed within 24 hours of the onset, and though the fasting blood glucose was normal, there was undoubted impairment of tolerance thereafter, the blood glucose level at 3 hours being $327 \mathrm{mg}$. $/ 100 \mathrm{ml}$.

It may be that a 6-hour fasting period is too long in an infant weighing $2 \mathrm{~kg}$. On 3-hourly feeds the blood glucose before feeds was over $200 \mathrm{mg}$. $/ 100 \mathrm{ml}$. There was no apparent impairment of renal function when hyperglycaemia developed, the increase in blood urea being consistent with slight dehydration. After insulin was started there was a rapid improvement in hydration, and hyperglycaemia was controlled. $\mathrm{He}$ appeared to be recovering when renal failure supervened. Although renal damage might have altered the renal threshold it is unlikely to have been responsible for the abnormal glucose tolerance test at onset. Polycystic disease of the pancreas is not known to cause symptoms, either exocrine or endocrine (Morison, 1963). In the present case it involved only the ducts and it is unlikely, therefore, that the diabetic state was associated with polycystic disease. The clinical picture in the early weeks was typical of the diabetic state associated with dysmaturity. Glucose tolerance test was not repeated after insulin was discontinued, but there was no return of hyperglycaemia and it is likely that he had recovered from the diabetic state before death.

Although the prognosis is good in reported cases, death occurred in the acute phase of hyperglycaemia in the case reported by Osborne (1965). A fatal outcome in neonatal diabetes has also been recorded in four other cases (Lewis and Eisenberg, 1935; Limper and Miller, 1935; Devine, 1938; Kitselle, 1852). It is doubtful, however, if these were of the type associated with dysmaturity. The infants described by Lewis and Eisenberg and by Limper and Miller were of normal birthweight and in both cases infection was present. Devine described hyperglycaemia in an infant of $1360 \mathrm{~g}$. birthweight 
at 28 weeks' gestation. In all 3 cases abnormalities of the pancreas were reported at necropsy. Kitselle in 1852 reported neonatal diabetes in his own son, who died at the age of 6 months. The infant, however, was described as plump and strong at birth, and it is possible that this was a case of permanent diabetes developing in the neonatal period.

The aetiology of the condition and its association with other forms of diabetes mellitus remain obscure. Abnormalities of the pancreas were noted in cases associated with infection, and a toxic effect on the pancreas postulated as a cause. Osborne, in his case where dysmaturity was the likely cause, described unusually large numbers of islets of Langerhans and there was no defect in islet cells in the present case. A toxic effect on the brain has been postulated (Strandqvist, 1932; Arey, 1953). Engleson and Zetterqvist (1957) favoured a carbohydrate disturbance of steroid diabetic character. With the introduction of insulin assay it is now possible to study insulin secretion in these cases. Lewis and Mortimer (1964) using the rat diaphragm method were unable to demonstrate insulin activity in a patient before treatment began. In a second case insulin secretion was demonstrated by immunoassay after recovery, but insulin antibodies had developed as a result of insulin therapy, making it impossible to determine absolute levels. They postulated temporary suppression of insulin secretion, or the presence of insulin antagonists. Chance and Bower (1966) found a plasma insulin level of $40 \mu \mathrm{U}$ by the immunoassay method 16 hours after a single injection of insulin, and thought that this suggested insulin antagonism. In the present case there was evidence of normal insulin levels and a normal response to glucose before onset. When hyperglycaemia developed the insulin level was higher though not outside the normal range. The response to intravenous tolbutamide was also normal and there was thus no evidence of abnormal insulin secretion either before or after hyperglycaemia developed.

Insulin antagonism is usually associated with resistance to insulin therapy, but in most of the reported cases, sensitivity to small doses of insulin has been a feature. Control is usually achieved on 4-8 units of insulin daily, a dosage similar to that required in the reported cases of permanent diabetes mellitus developing in the neonatal period. The infant reported by Osborne was probably insulin resistant, for despite a dosage of 3 units before feeds, blood sugar rose to $1450 \mathrm{mg}$. $/ 100 \mathrm{ml}$. before death. In this case the liver at necropsy was only one-third normal size. Diminution in liver size in dysmaturity has been reported (Cornblath, Wybregt, and Baens, 1963) and the hypoglycaemia which these infants may develop is thought to be due to depleted glycogen stores (Shelley, 1964; Dawkins, 1964). As both conditions may occur in the same infant, it seems possible that they have an associated aetiology. A temporary immaturity of hepatic enzyme systems, due to intrauterine malnutrition, might explain both conditions.

\section{Summary and Conclusion}

Temporary neonatal hyperglycaemia occurred in a dysmature infant who died at age $3 \frac{1}{2}$ months of renal failure. Polycystic disease of kidneys, pancreas, and lungs was found at necropsy, but there was no evidence that this was related causally to the hyperglycaemia. Insulin studies after birth and at onset suggested that secretion of insulin by the pancreas was normal.

Immaturity of a hepatic enzyme system is postulated as a cause of temporary neonatal hyperglycaemia.

Thanks are due to Professor J. H. Hutchison for advice and encouragement.

\section{REFERENCES}

Arey, S. L. (1953). Transient diabetes in infancy. Pediatrics, 11, 140.

Campbell, M. A., Ferguson, I. C., Hutchison, J. H., and Kerr, M. M. (1967). Diagnosis and treatment of hypoglycaemia in the newborn. Arch. Dis. Childh., 42, 353.

Chance, G. W., and Bower, B. D. (1966). Hypoglycaemia and temporary hyperglycaemia in infants of low birth weight for maturity. ibid., 41, 279.

Cornblath, M., Wybregt, S. H., and Baens, G. S. (1963). Studies of carbohydrate metabolism in the newborn infant. VII. Tests of carbohydrate tolerance in premature infants. Pediatrics, 32, 1007 .

Dawkins, M. J. R. (1964). Hypoglycaemia in childhood. Proc. roy. Soc. Med., 57, 1063.

Devine, J. (1938). A case of diabetes mellitus in a young infant. Arch. Dis. Childh., 13, 189.

Engleson, G., and Zetterqvist, P. (1957). Congenital diabetes mellitus and neonatal pseudodiabetes mellitus. ibid., 32, 193.

Gans, B. (1953). Diabetes mellitus in an infant aged 39 days. Proc. roy. Soc. Med., 47, 132.

Guest, G. M. (1949). Diabetes mellitus in early infancy, treated without dietary restrictions. Acta paediat. (Uppsala), 38, 196.

Hales, C. N., and Randle, P. J. (1963). Immunoassay of insulin with insulin antibody precipitate. Lancet, 1, 200; Biochem. F., 88, 137.

Hofman-Bang, E. (1954). Diabetic coma in a three weeks old infant. (Proc. of Section for Pediatrics and School Hygiene of the Swedish Medical Society.) Acta paediat. (Uppsala), 43, 393.

Hutchison, J. H., Keay, A. J., and Kerr, M. M. (1962). Congenital temporary diabetes mellitus. Brit. med. $\mathcal{F}$., $2,436$.

Kitselle (1852). F. Kinderheilk., 18, 313. (Cited by Lawrence, R. D., and McCance, R. A., Gangrene in an infant associated with temporary diabetes, 1931, Arch. Dis. Childh., 6, 343.)

Lewis, E., and Eisenberg, H. (1935). Diabetes mellitus neonatorum. Report of a probable case. Amer. F. Dis. Child., 49, 408.

Lewis, S. R., and Mortimer, P. E. (1964). Idiopathic neonatal hyperglycaemia. Arch. Dis. Childh., 39, 618.

Limper, M. A., and Miller, A. J. (1935). Diabetes mellitus with extensive gangrene in early infancy. Amer. F. Dis. Child., 50, 1216. 
Marks, V. (1959). An improved glucose-oxidase method for determining blood, C.S.F. and urine glucose levels. Clin. chim. Acta, 4, 395.

Morison, J. E. (1963). Pancreatic cysts. In Foetal and Neonatal Pathology, 2nd ed., p. 310. Butterworth, London.

Neligan, G. A. (1965). Idiopathic hypoglycaemia in the newborn. In Recent Advances in Paediatrics, 3rd ed., ed. D. Gairdner, p. 110. Churchill, London.

- Robson, E., and Watson, J. (1963). Hypoglycaemia in the newborn. A sequel of intrauterine malnutrition. Lancet, 1, 1282.
Osborne, G. R. (1965). Congenital diabetes. In Paediatric Pathology Club. Proceedings of the Tenth Annual Meeting. Arch. Dis. Childh., 40, 332.

Shelley, H. J. (1964). Carbohydrate reserves in the newborn infant. Brit. med. f., 1, 273.

med. Bull., 22, 34.

Strandqvist, B. (1932). Infantile glycosuria simulating diabetes. Acta paediat. (Uppsala), 13, 421.

The following articles will appear in future issues of this Journal:

Dissecting Microscope Appearance of Small Bowel Mucosa in Children. By John Walker-Smith.

Paraproteinaemia and Unusual Dysgammaglobulinaemia in a Case of Wiskott-Aldrich Syndrome. An Immunochemical Study. By J. Rádl, J. Masopust, J. Houštěk, and O. Hrodek.

Observations on Nicotinic Acid Therapy in Hartnup Disease. By Paul W. K. Wong, A. M. Lambert, P. M. Pillai, and P. M. Jones.

Lead Poisoning in Children in Ceylon. By E. H. Mirando and Manel Gomez.

Diagnostic Problems in Severe Neonatal Jaundice and G6PD Deficiency in Greece. By L. ZannosMariolea, Th. Thomaidis, G. Georgizas, E. Gavrielidou, and S. Benetos.

Lymphocytic (Auto-immune, Hashimoto's) Thyroiditis. Presentation of an Unusual Case with Subacute Onset in a 14-year-old Girl. By J. R. Humbert, R. W. Gotlin, G. Hostetter, J. G. Sherill, and H. K. Silver.

Neurological Evaluation of the Maturity of Newborn Infants. By C. Amiel-Tison.

Serum Anti-staphylococcal Alpha-haemolysin Titres in Cystic Fibrosis. By V. F. Iacocca and G. J. Barbero

Congenital Sensory Neuropathy with Anhidrosis. By F. Vassella, H. M. Emrich, R. Kraus-Ruppert, F. Aufdermaur, and O. Tönz.

Hereditary Quivering of the Chin. By B. M. Laurence, W. B. Matthews, and J. H. Diggle.

The Rubenstein-Taybi Syndrome. By C. J. Padfield, M. W. Partington, and N. E. Simpson.

The Rubenstein-Taybi Syndrome: A Report of Two Cases. By M. A. Salmon.

Acute Leukaemia 1959-64: Factors Affecting Prognosis. By R. M. Hardisty and Morwenna M. Till.

Serum Magnesium Level in the Salt-losing Type of Congenital Adrenal Hyperplasia. By A. Kobayashi and Y. Igarashi.

Functional and Structural Changes of Small Intestine in Children with Hookworm Infection. By D. K. Guha, B. N. S. Walia, B. N. Tandon, and O. P. Ghai.

Normal Values of Forced Vital Capacity (FVC), Forced Expiratory Volume $\left(\mathrm{FEV}_{1 \cdot 0}\right.$ ), and Peak Flow Rate (PFR) in Children. By A. E. Dugdale and M. Moeri. 